\title{
Circulation in the Arctic Ocean
}

\author{
E. Peter Jones
}

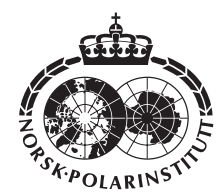

\begin{abstract}
Much information on processes and circulation within the Arctic Ocean has emerged from measurements made on icebreaker expeditions during the past decade. This article offers a perspective based on these measurements, summarizing new ideas regarding how water masses are formed and how they circulate. Best understood at present is the circulation of the Atlantic Layer and mid-depth waters, to depths of about $1700 \mathrm{~m}$, which move in cyclonic gyres in the four major basins of the Arctic Ocean. New ideas on halocline formation and circulation are directly relevant to concerns regarding changes in ice thickness. The circulation of the halocline water in part mimics that of the underlying Atlantic Layer. A number of large eddies contributing to water mass transport have been observed. The circulation of freshwater from the Pacific Ocean and from river runoff has been better delineated. Circulation within the surface layer resembles the circulation of ice, but is different in several respects. Least understood is the circulation of the deepest waters, though some information is available. Recent observed changes in the surface waters and warm Atlantic Layer have been correlated with the North Atlantic Oscillation. While these changes are dramatic, the qualitative circulation pattern may not have been altered significantly.
\end{abstract}

E. P. Jones, Dept. of Fisheries and Oceans, Bedford Institute of Oceanography, Box 1006, Dartmouth NS B2Y 4A2, Canada.

The Arctic Ocean is an enclosed ocean, connected to the Pacific Ocean through the Bering Strait and the Bering Sea, and to the Atlantic Ocean through Fram Strait and the Barents Sea via the Greenland and Norwegian seas as well as through the Canadian Arctic Archipelago via Baffin Bay. The Arctic Ocean has a total area of approximately $9.4 \times 10^{6} \mathrm{~km}^{2}$, with the continental shelves constituting about one-third of this area. The central Arctic Ocean Basin is separated by the subsurface Lomonosov Ridge, which extends from North America to the Eurasian continent passing close to the North Pole, into the Eurasian Basin on the Atlantic side and the Canadian Basin on the Pacific side. These two basins are each further subdivided by less prominent subsurface ridges: the Nansen-Gakkel Ridge, which separates the Eurasian Basin into the Nansen and Amundsen basins, and the Alpha-Mendeleyev Ridge, which separates the Canadian Basin into the Makarov and Canada basins (Fig. 1).

In this paper the discussion of the origin and description of water masses and their circulation is based on observations. Models can give much insight into what is happening in the Arctic Ocean (e.g. Maslowski et al. 2000, and references therein). To include a discussion of models is beyond the scope of this presentation.

\section{Water masses}

Water flows into the Arctic Ocean from the North Atlantic and Pacific oceans. Most of the Arctic Ocean water originates in the North Atlantic Ocean, which provides a substantial portion of 


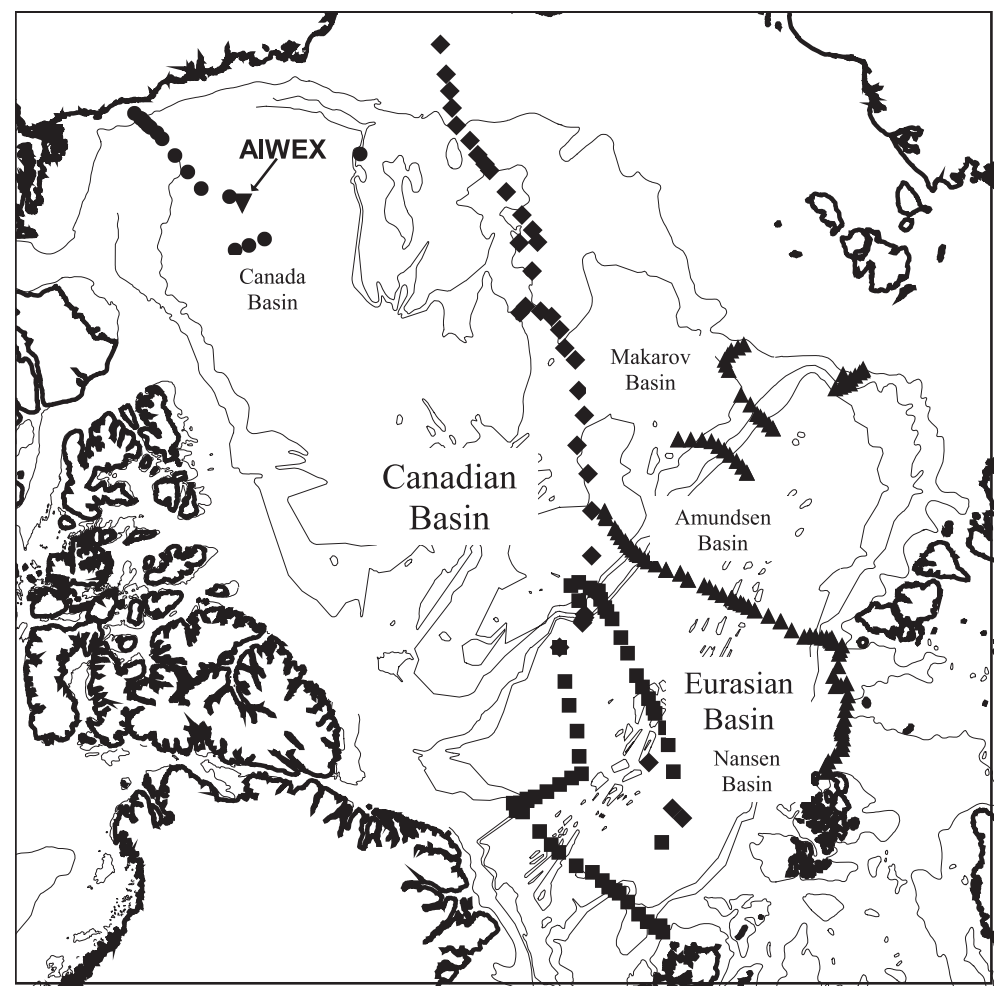

Fig. 1. Map of the Arctic Ocean, symbols indicate recent expeditions: squares $=$ Oden 91; diamonds $=$ Arctic Ocean Sections 94; triangles $=$ ACSYS 96; circles $=$ JOIS 97 .

upper waters and almost all of the mid-depth and deep waters. From the North Atlantic Ocean, water enters through Fram Strait between Greenland and Svalbard and through the Barents Sea. There is more evaporation than precipitation in the Atlantic Ocean, and much of the evaporated water falls as rain into the Pacific Ocean or is carried there by rivers flowing into it. A significant pathway for the return of fresh water from the Pacific Ocean to the North Atlantic Ocean is through the Arctic Ocean. A substantial amount of freshwater also enters the Arctic Ocean via rivers that flow directly into it.

As it enters the Arctic Ocean, warm North Atlantic surface water flowing through Fram Strait encounters ice, melting it and becoming fresher, and thereby forming an embryonic halocline (Rudels et al. 1996). Deeper, denser warm water (about $3{ }^{\circ} \mathrm{C}$ ) forms the Atlantic Layer, defined conventionally in the Arctic Ocean as having a potential temperature $(\theta)$ greater than $0{ }^{\circ} \mathrm{C}$. Colder water enters down to the depth of the sill, $2300 \mathrm{~m}$. North Atlantic water entering the Barents Sea is "skimmed off" by the shallow depth of the Barents Sea, and is freshened as it encounters and melts sea ice. Two significant winter processes occur within the Barents that change the density of the inflowing Atlantic water and determine its subsequent distribution within the Arctic Ocean. There is a large heat loss and addition of salt as brine is injected as ice forms. These two processes-cooling and addition of salt- "spread" the density range of the water in the Barents Sea, making it dense enough to flow off the shelf in plumes. These shelf-slope plumes entrain and mix with water as they sink, and, according to their density, can penetrate to all depths (Rudels et al. 1994; Jones et al. 1995).

Pacific water flows into the Arctic Ocean north of Alaska from the Bering Sea through the shallow (50 m deep) Bering Strait. The relatively fresh and cold water originating in the Pacific Ocean flows from the Bering Sea into the Chukchi Sea. The Pacific water brings in high concentrations of silicate that has been used as a tracer of Pacific source water in the halocline and deeper (e.g. Jones \& Anderson 1986; Anderson et al. 1994; Swift et al. 1997; Wheeler et al. 1997). As in the Barents Sea, brine injected as ice forms produces dense water that can trigger shelf-slope 
Fig. 2. Schematic circulation of surface water (grey arrows) and the Atlantic Layer plus Upper Polar Deep Water to depths of about $1700 \mathrm{~m}$ (black arrows). The straight arrows represent the mouths of major rivers.

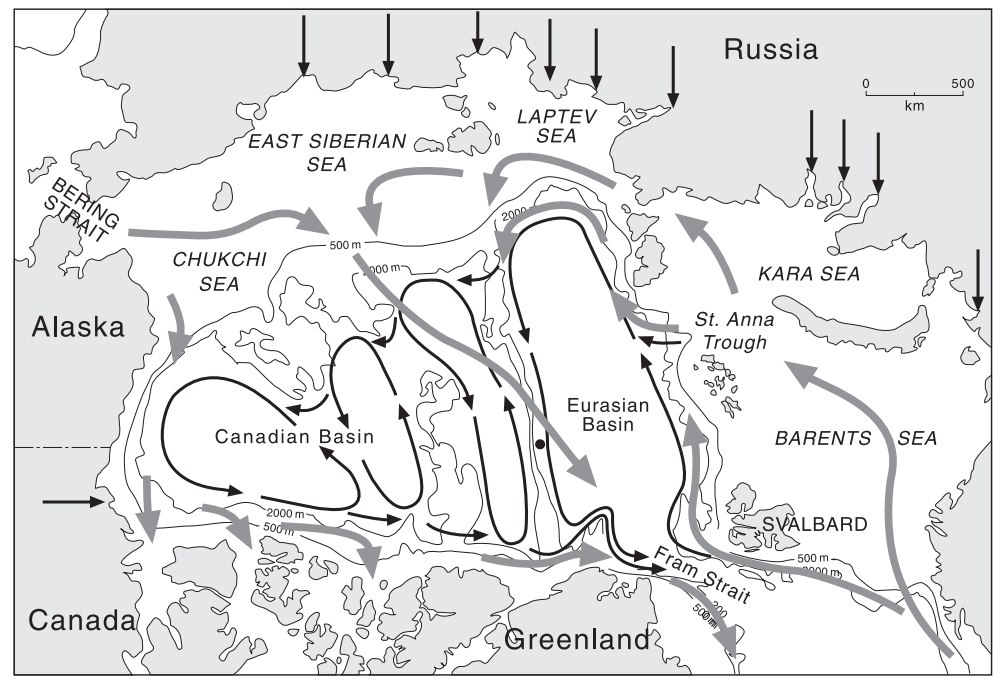

plumes, which penetrate and entrain water as they sink. These plumes are suggested to carry silicate from the near surface and heat from the warm Atlantic Layer into deeper regions of the Canadian Basin, making the deep water warmer and silicate concentrations higher than otherwise (Jones et al. 1995).

There have been considerable differences in estimates of flows into and out of the Arctic Ocean. The values quoted here are those thought to be the best in a recently summarized set of values (Rudels \& Friedrich 2000). The two pathways from the North Atlantic result in two flows within the Arctic Ocean, the Fram Strait branch $\left(1-1.5 \mathrm{~Sv}\left[1 \mathrm{~Sv}=10^{6} \mathrm{~m}^{3} \mathrm{~s}^{-1}\right]\right)$ and the Barents Sea branch (2 Sv). Water of Pacific origin $(0.8 \mathrm{~Sv})$ and river runoff $(0.1 \mathrm{~Sv})$ contribute mainly to the near surface layers in the Canadian Basin. Near surface water exits through the Canadian Archipelago (1 Sv) and together with deeper water through Fram Strait (3 - $3.5 \mathrm{~Sv})$.

The Arctic Ocean can be characterized by a Polar Mixed Layer (PML) at the surface, a cold halocline separating the PML from a warm Atlantic Layer, Upper Polar Deep Water (UPDW, characterized by a negative potential temperature-salinity $[\theta-S]$ relationship) extending to an average depth of the Lomonosov Ridge (about $1700 \mathrm{~m}$ ), deep water extending to a depth of about $2500 \mathrm{~m}$, and bottom water beneath that. The most prominent feature found in profiles in the Arctic Ocean is the warm Atlantic Layer (AL) at depths ranging between 200 and $500 \mathrm{~m}(34.5<\mathrm{S}<34.8)$.
The temperature maximum is greatest in the Eurasian Basin, as high as about $2{ }^{\circ} \mathrm{C}$, and lowest in the Canadian Basin, near $0.5^{\circ} \mathrm{C}$. The cold, low salinity PML, typically $50 \mathrm{~m}$ deep $(31<\mathrm{S}<34)$ is isolated from the Atlantic Layer by a cold, almost isothermal halocline in large regions of the Arctic Ocean. The UPDW $\left(0{ }^{\circ} \mathrm{C}>\theta>-0.5{ }^{\circ} \mathrm{C}, 34.85\right.$ $<\mathrm{S}<34.9)$ is cooler and fresher that the AL. The salinity and temperature of the deepest water in the Eurasian Basin is 34.94 and $-0.95{ }^{\circ} \mathrm{C}$. In the Canadian Basin, the corresponding values are 34.95 and $-0.53{ }^{\circ} \mathrm{C}$.

\section{Circulation}

\section{Polar Mixed Layer}

Determining the circulation of the PML has been problematic. In recent times, it was mostly assumed that the surface water flow was represented by ice drift. With a new approach using nutrients as tracers, Jones et al. (1998) inferred a somewhat different pattern (Fig. 2). In general terms, Atlantic water entering through eastern Fram Strait and the Barents Sea flows eastward, turns north somewhere in the vicinity of the Lomonosov Ridge, then follows the ridge in a return flow to exit through western Fram Strait. Pacific water entering through Bering Strait splits in the Chukchi Sea region with one branch flowing along the coast of North America and the other 
flowing north eventually to partially mix with the Atlantic water. Pacific water exits the Arctic Ocean through the Canadian Arctic Archipelago and through western Fram Strait. Wind fields as characterized by the North Atlantic Oscillation Index (NAO) are considered to be a major factor in determining ice and surface water flow (Proshutinsky \& Johnson 1997; Maslowski et al. 2000). While the surface water flow pattern is not well resolved, it is consistent with ice drift in the central Arctic Ocean. Ice drift and surface water flow differ near Fram Strait, where surface water of Atlantic origin enters through eastern Fram Strait, rather than exiting, as does the ice. And there are indications of a coastal current in the Beaufort Sea (e.g. Jones et al. 1998) that is not apparent in ice motion (Rigor \& Ortmeyer 2000).

In a context of climate and climate change, the PML is the major pathway for fresh water from river runoff into the Arctic Ocean and for the freshwater return flow from the Pacific to reach the North Atlantic Ocean (e.g. Schlosser et al. 2000). In addition, the PML is the pathway for heat transport to the atmosphere. In large regions of the Arctic Ocean, this heat transport is much inhibited by the cold halocline between the PML and the warm AL. Recent observations show that the PML is in contact with the AL in the Eurasian Basin (Rudels et al. 1996; Steele \& Boyd 1998; Schauer et al. in press), and that changes in the extent of this contact have occurred coincident with changes in the distribution of river runoff (Steele \& Boyd 1998).

\section{The halocline}

The embryonic halocline is formed when the warm West Spitsbergen Current (Atlantic) water meets the ice edge, becomes cooled and freshened (Rudels et al. 1996). The inflowing water progresses along the continental shelf, undergoing cycles of freezing and thawing with convection down to the top of the Atlantic Layer, until fresher water from the Laptev Sea provides a cap that prevents such convection. Water of Pacific origin and modified on the Chukchi Sea shelf is subsequently injected into the halocline in the Canada Basin. The circulation of halocline waters is not well delineated. A reasonable hypothesis is that the flow resembles that of the Atlantic Layer, with additions of Pacific origin water from the Chukchi shelf.
Atlantic Layer and Upper Polar Deep Water

In the Eurasian Basin a broad circulation pattern (Fig. 2), originally based on data from Oden 91 expedition (Anderson et al. 1994) and the Arctic Internal Wave Experiment (AIWEX) ice camp (Anderson \& Swift 1990), seems pretty well defined for the AL and UPDW (Rudels et al. 1994; Rudels et al. 1996). In the Eurasian Basin, the Fram Strait branch flows in a boundary current north of the Barents Sea. North of the Kara Sea, it encounters the Barents Sea branch. Here part of the Fram Strait branch leaves the boundary to flow north to begin a return flow in the vicinity of the Nansen-Gakkel Ridge, and part joins the Barents Sea branch to continue as a boundary current. Near the Lomonosov Ridge this flow divides, with warmer water turning north to follow the ridge, and colder water continuing in a boundary flow into the Canadian Basin.

The Eurasian Basin circulation picture has been refined as a result of subsequent ACSYS-96 observations (Schauer et al. in press). The AL exhibits a large warm core (stations 35 to 38) and four distinct warmer features across the section: in the Nansen Basin (station 42 near $250 \mathrm{~m}$ ), in the Amundsen Basin (station 54 near $400 \mathrm{~m}$ ), and at each side of the Lomonosov Ridge (station 60 near $250 \mathrm{~m}$ and Station 70 near $250 \mathrm{~m}$ ) (Fig. 3). The water properties correspond to the inflow through Fram Strait and the various return flows. Their structure suggests that only the warmest water close to the slope and the warm core on the Amundsen Basin side of the Lomonosov Ridge are continuous streams. Eddy-like features containing Fram Strait water point to an instability of the Fram Strait branch of Atlantic water. This branch flows as a boundary current, but north of the Kara Sea it is pushed off the slope by the Barents Sea branch. Topographic steering no longer constrains its flow to a narrow boundary current. Much of the return flow in the Eurasian Basin is likely carried in broad circulation loops with eddies or lenses added to a weak return flow in the vicinity of the Nansen-Gakkel Ridge. East of the confluence region, only the part of the Fram Strait branch that has been mixed into the Barents Sea branch will remain in the boundary current at the slope.

In the Amundsen Basin, a warm, saline water mass $\left(-0.7<\theta<-0.6{ }^{\circ} \mathrm{C}, \mathrm{S}>34.93\right)$ having an oxygen maximum was observed at depths between $1500 \mathrm{~m}$ and $2600 \mathrm{~m}$ at station 51 (not 
Fig. 3. Distribution of intermediate depth water masses in the eastern Eurasian Basin and across the Lomonosov Ridge (Lomo R): (a) potential temperature $\left({ }^{\circ} \mathrm{C}\right)$; (b) salinity; and (c) potential density, sigma 0 $\left(\mathrm{kg} / \mathrm{m}^{3}\right)$ (Schauer et al. in press figure printed with permission of U. Schauer and Annales Geophysicae).
Nansen B

Amundsen $B$

Lomo R

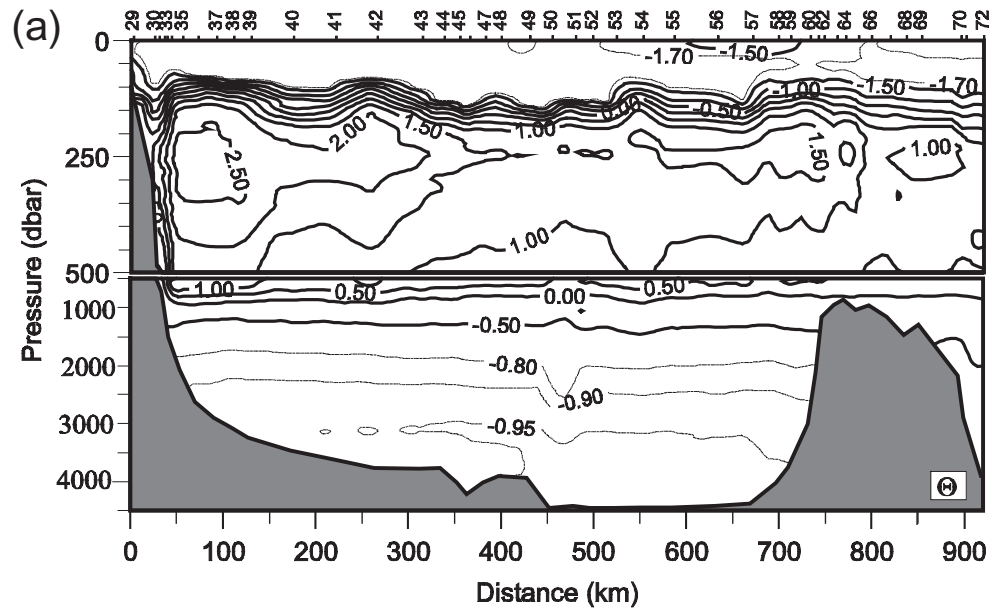

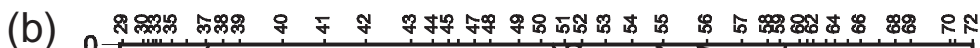
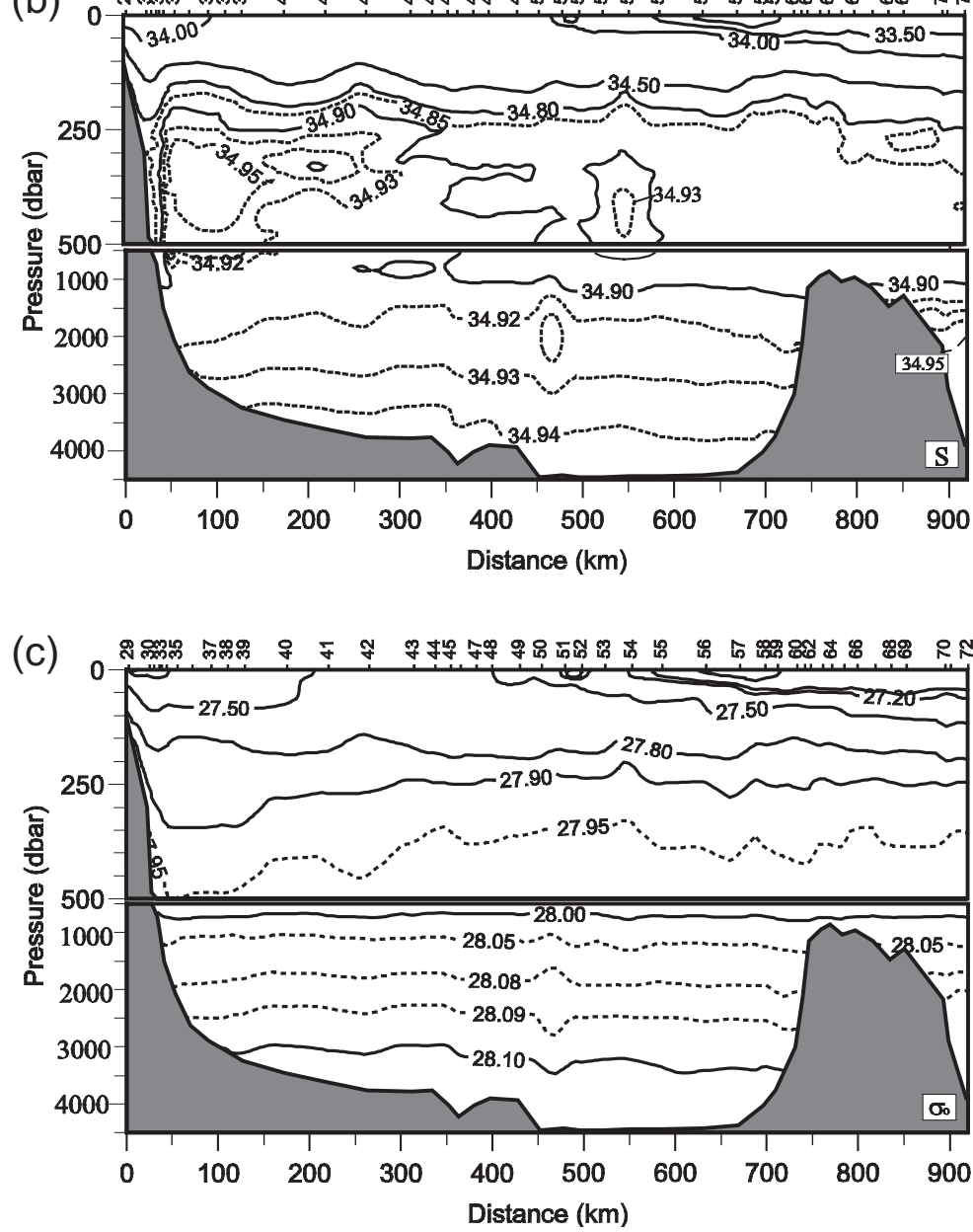


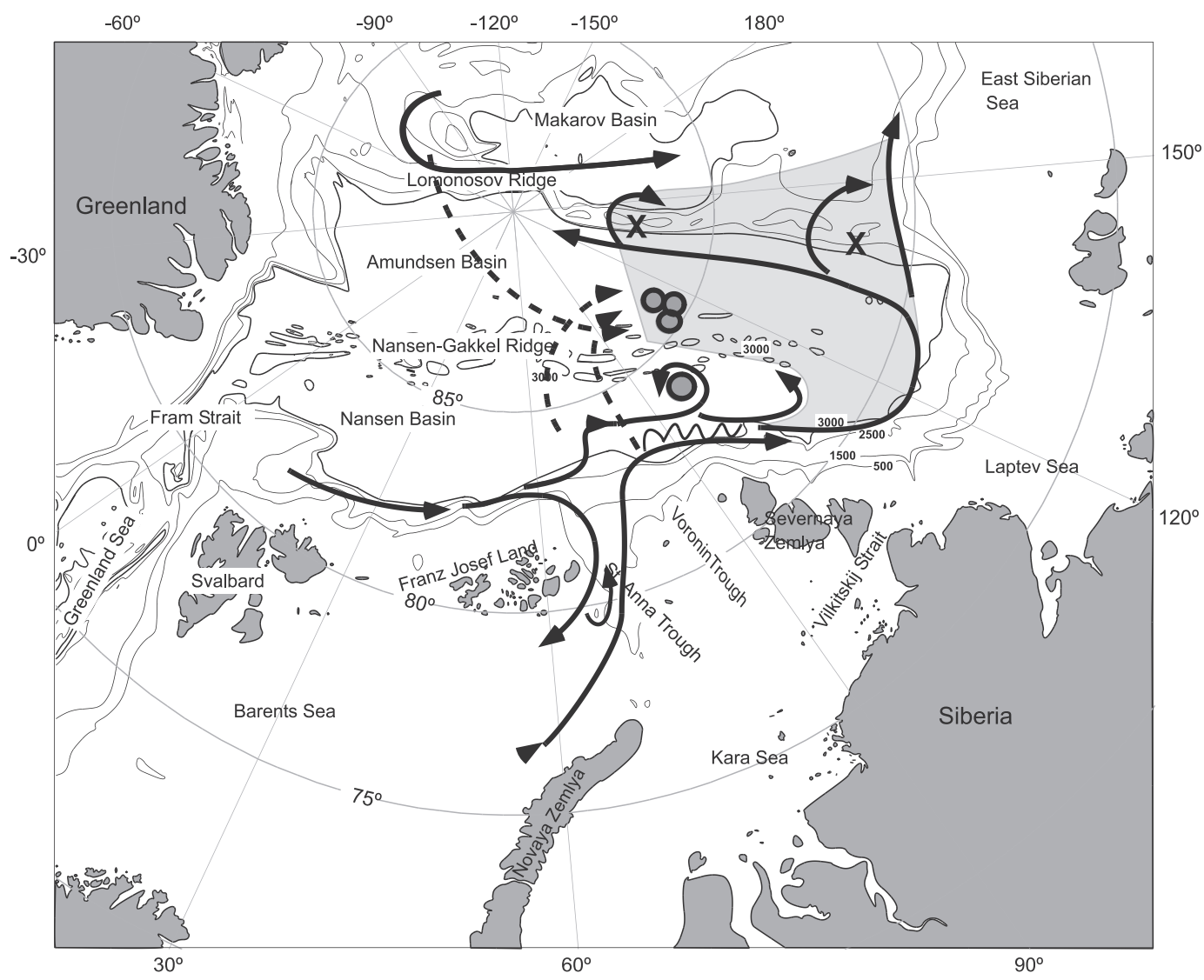

Fig. 4. Circulation of intermediate depth waters in the Eurasian Basin (Schauer et al. in press; figure printed with permission of U. Schauer and Annales Geophysicae). Solid-line arrows in the Eurasian Basin display the flow of the Fram Strait branch, the Barents Sea branch, and their mixing east of their confluence. The light grey shading shows the region dominated by the mixed water type. The grey-filled circles denote eddy-like structures as described in the text. The solid-line arrow in the Makarov Basin denotes the flow of Upper Polar Deep Water (Rudels et al. 1994). Crosses denote the position of elevations of the Lomonosov Ridge of less than $1000 \mathrm{~m}$ water depth, possibly steering the cross-ridge flow of intermediate depth waters. The dashed arrows connect the anomalous water parcels with their area of origin, but are not meant to represent pathways.

shown). Its characteristics were close to those of Canadian Basin Deep Water. At the neighbouring station in the Amundsen Basin (station 52), a cold lens of low salinity water with a weak oxygen maximum was observed around $1000 \mathrm{~m}$ depth. It was even colder than the water of the Barents Sea branch at the continental slope, but similar characteristics were observed in the St. Anna Trough. These isolated features from remote source areas are detached eddies migrating through the basin, contributing to the slope basin and inter-basin exchange, and contributing to a weak continuous flow more-or-less following the Nansen-Gakkel Ridge. They also contribute to the flow of Canadian Basin water into the Eurasian Basin (Rudels et al. 1994; Jones et al 1995; Schauer et al. in press).

The newer data also clarify the flow from the Eurasian Basin into the Canadian Basin. The general scheme of Fig. 2 scheme suggests that a welldefined boundary current of a mixture of the Fram Strait and Barents Sea branches flows from the Eurasian Basin into the Makarov Basin. These data shows that Eurasian Basin waters enter the Canadian Basin in a broad flow not just along the continental slope, but also crossing the Lomonosov Ridge at topographical irregularities (Fig. 4).

Within the Canadian Basin, the situation is less clear, partly because of a present lack of data in central regions of the basin. Measurements 
near the Morris Jesup Plateau clearly showed the existence of three water masses corresponding to properties observed in the Amundsen Basin, in the Makarov Basin, and a third water mass that must have originated in the Canada Basin (Rudels et al. 1994). In addition, measurements identified the existence of another water mass in the Canada Basin (AIWEX data and confirmed by the 1997 Joint Ocean-Ice Study [JOIS 97] data [unpublished]) that was not seen at the Morris Jesup Plateau (Rudels et al. 1996). CFC measurements from Arctic Ocean Sections 94 that skirted the Canada Basin (Fig. 1) showed that water flowing over the Lomonosov Ridge is injected into the central Canadian Basin at the Mendeleyev Ridge and at the Chukchi Plateau (Swift et al. 1997), consistent with the general scheme of Fig. 2. Recent CFC measurements in the Canadian Basin show the oldest UPDW water in the Canadian Basin to be at the northernmost end of the Canada Basin, suggesting a gyre isolated from more recently formed water (Smethie et al. 2000). These data are consistent with, but do not indisputably confirm, the circulation scheme within the Canadian Basin presented in Fig. 2.

\section{Deep and bottom water}

In general, the flow of water below $1700 \mathrm{~m}$ has not been well determined. The water from about $1700 \mathrm{~m}$ to a depth of about $2500 \mathrm{~m}$ is of Atlantic origin, likely a mixture of some water from Fram Strait (Norwegian Sea Deep Water) and Barents Sea branch water (Anderson et al. 1994; Rudels et al. 1994; Frank et al. 1999). The Eurasian Basin Bottom Water is too saline and dense to have entered directly through Fram Strait. It must have a different origin, most likely arising from shelfslope plumes triggered by a flow of dense water from the Barents and Kara seas down the St. Anna Trough. The deep water in the Canadian Basin is mostly water from the Eurasian Basin that has spilled into the Makarov Basin through gaps in the Lomonosov Ridge (e.g. Jones et al. 1995), at least one of which extends to a depth more than $2400 \mathrm{~m}$ (International Bathymetric Chart of the Arctic Ocean, 2000). From the Makarov Basin, water spills over the Alpha-Mendeleyev Ridge into the Canada Basin. Below the sill depth of the Lomonosov Ridge, the water in the Canadian Basin is warmer and more saline than that in the Eurasian Basin, having been warmed and made more saline by shelf-slope plumes that cool the Atlantic Layer and carry heat, salt and nutrients to deeper regions (Jones et al. 1995). The residence times of these waters are long, perhaps one hundred years or more in the Eurasian Basin and several hundred years in the Canadian Basin (Schlosser et al. 1994; Jones et al. 1995), and the circulation is presumed to be cyclonic.

\section{Summary remarks}

During the past decade unexpected changes have been observed in the Arctic Ocean. The most dramatic of these must be the increased temperature of the Atlantic Layer (e.g. Quadfasel et al. 1991; Carmack et al. 1995; Morison et al. 1998). At the same time, there was a redistribution in the waters of the surface layer and halocline (e.g. McLaughlin et al. 1996; Newton \& Sotirin 1997; Smith et al. 1999). These changes and changes in ice drift correlate well with changes in atmospheric circulation as implied by the presently high positive values of the North Atlantic Oscillation (NAO) Index (Swift et al. 1997). Whether these represent changes in the broad flow pattern or whether they are changes in the water in the "pipes" is still in question. Generally, the flow seems to be strongly influenced by bathymetry, and that has not changed. There is evidence from the extensive surveys carried out by the former Soviet Union that similar changes have occurred in the past (G. Alekseev, pers. comm.), and there is an indication that ice drift is returning to a previous pattern (Rigor \& Ortmeyer 2000).

The PML is of direct relevance to understanding climate and climate change because it transports freshwater that influences and/or controls deep water formation in the northern regions of the thermohaline circulation (Arctic Ocean, Nordic seas, Labrador Sea). Surface water flow is difficult to trace, but it is clear that it differs significantly from ice drift in some regions.

The circulation of the Atlantic Layer and UPDW (Fig. 2), where observations most easily lend themselves to interpretation, seems to be correct in the broadest sense. The nature of the circulation, whether paths represent continuous flow or eddy transport and whether they contain greater or smaller amounts of particular water masses, is subject to further refinement. Some aspects of the halocline circulation are reasonably clear; some are as yet unresolved. The deep and bottom water 
circulation patterns remain mostly unknown. While variability in water properties and/or circulation at all depths could reflect changing climatic conditions (e.g. the observed warmer Atlantic Layer), variability in surface waters will likely have a more direct effect on global climate through changes in the heat exchange between the PML and the atmosphere and through the effect of freshwater outflow on deep convection regions of the global thermohaline circulation.

\section{References}

Anderson, G. C. \& Swift, J. H. 1990. Arctic internal wave experiment (AIWEX) hydrographic data. SIO Reference 90-10. La Jolla, CA: Scripps Institution of Oceanography.

Anderson, L. G., Björk, G., Holby, O., Jones, E. P., Kattner, G., Koltermann, K.-P., Liljeblad, B., Lindegren, R., Rudels, B. \& Swift, J. H. 1994: Water masses and circulation in the Eurasian Basin: results from the Oden 91 Expedition. $J$. Geophys. Res. 99(C2), 3273-3283.

Carmack, E. C., Macdonald, R. W., Perkin, R. G., McLaughlin, F. A. \& Pearson, R. J. 1995: Evidence for warming of Atlantic water in the southern Canadian Basin of the Arctic Ocean: results from the Larsen-93 expedition. Geophys. Res. Lett. 22, 1061-1064.

Frank, M., Smethie, Jr., W. M. \& Bayer, R. 1999: Investigation of subsurface water flow along the continental margin of the Eurasian Basin using the transient tracers tritium, ${ }^{3} \mathrm{He}$, and CFCs. J. Geophys. Res. 103(C13), 30,773-30,792.

International Bathymetric Chart of the Arctic Ocean (IBCAO) 2000: http://www.ngdc.noaa.gov/mgg/bathymetry/arctic. html.

Jones, E. P. \& Anderson, L. G. 1986: On the origin of the chemical properties of the Arctic Ocean halocline. J. Geophys. Res. 91(C9), 10759-10767.

Jones, E. P., Rudels, B. \& Anderson, L. G. 1995: Deep waters of the Arctic Ocean: origins and circulation. Deep-Sea Res. 42, 737-760.

Jones, E. P., Anderson, L. G. \& Swift, J. H. 1998: Distribution of Atlantic and Pacific waters in the upper Arctic Ocean: implications for circulation. Geophys. Res. Lett. 25, 765-768.

Maslowski, W., Newton, B., Schlosser, P., Semtner, A. \& Martinson, D. 2000: Modeling recent climate variability in the Arctic Ocean. Geophys. Res. Lett. 27,3743-3746.

McLaughlin, F., Carmack, E. C., Macdonald, R. W. \& Bishop, J. K. B. 1996: Physical and geochemical properties across the Atlantic/Pacific water mass front in the southern Canadian Basin. J. Geophys. Res. 101(C1), 1183-1197.

Morison, J., Steele, M. \& Andersen, R. 1998: Hydrography of the upper Arctic Ocean measured from the nuclear submarine U.S.S. Pargo. Deep-Sea Res. 45, 15-38.
Newton, J. L. \& Sotirin, B. J. 1997: Boundary undercurrent and water mass changes in the Lincoln Sea. J. Geophys. Res. 102(C2), 3393-3403.

Proshutinsky, A. Y. \& Johnson, M. A. 1997: Two circulation regimes of the wind-driven Arctic Ocean. J. Geophys. Res. 102(C6), 12,493-12,514.

Quadfasel, D., Sy, A., Wells, D. \& Tunik, A. 1991: Warming in the Arctic. Nature 350, 385.

Rigor, I. \& Ortmeyer, M. 2000: Observations of sea level pressure, surface air temperature and ice motion from the International Arctic Buoy Programme. Applied Physics Laboratory Technical Report 9902. Also available at http:// iapb.apl.washington.edu/Summary/index.html.

Rudels, B. Anderson, L. G. \& Jones, E. P. 1996: Formation and evolution of the surface mixed layer and halocline of the Arctic Ocean. J. Geophys. Res. 101(C4), 8807-8821.

Rudels, B. \& Friedrich, H. J. 2000: The transformations of Atlantic water in the Arctic Ocean and their significance for the freshwater budget. In E. L. Lewis (ed.): The freshwater budget of the Arctic Ocean. Pp. 503-532. Dordrecht: Kluwer Academic Press.

Rudels, B., Jones, E. P., Anderson, L. G. \& Kattner, G. 1994: On the intermediate depth waters of the Arctic Ocean. In $\mathrm{O}$. M. Johannessen et al. (eds.): The role of polar oceans in shaping the global climate. Pp. 33-46. Washington, D.C.: American Geophysical Union.

Schauer, U., Rudels, B., Jones, E. P., Anderson, L. G., Muench, R. D., Björk, G., Swift, J. H., Ivanov, V. \& Larsson, A.-M. in press: Confluence and redistribution of Atlantic waters in the Eurasian Basin and the Canadian Basin: results from ACSYS-96. Ann. Geophys.

Schlosser, P., Ekwurzel, B., Khatiwala, S., Newton, B., Maslowski, W. \& Pfirman, S. 2000: Tracer studies of the Arctic freshwater budget. In E. L. Lewis (ed.): The freshwater budget of the Arctic Ocean Pp. 453-478. Dordrecht: Kluwer Academic Press.

Schlosser, P., Kromer, B., Östlund, G., Ekwurzel, B., Bönisch, G., Loosli, H. H. \& Purtschert, P. 1994: On the ${ }^{14} \mathrm{C}$ and ${ }^{39} \mathrm{Ar}$ distribution in the central Arctic Ocean: implications for deep water formation. Radio Carbon 36, 327-343.

Smethie, W. M., Jr., Schlosser, P. \& Bönisch, G. 2000: Renewal and circulation of intermediate waters in the Canadian Basin observed on the SCICEX 96 cruise. J. Geophys. Res. 105(C1), 1105-1121.

Smith, J. N., Ellis, K. M. \& Boyd, T. 1999: Circulation features in the central Arctic Ocean revealed by nuclear fuel reprocessing tracers from Scientific Ice Expeditions 1995 and 1996. J. Geophys. Res. 104(C12), 29,663-29,677.

Steele, M. \& Boyd, T. 1998: Retreat of the cold halocline layer in the Arctic Ocean. J. Geophys. Res. 103(C5), $10,419-10,435$.

Swift, J. H., Jones, E. P., Aagaard, K., Carmack, E. C., Hingston, M., Macdonald, R. W., McLaughlin, F. A. \& Perkin, R. G. 1997: Waters of the Makarov and Canada basins. Deep-Sea Res. 44, 1503-1529.

Wheeler, P. A., Watkins, J. M. \& Hansing, R. L. 1997: Nutrients, organic carbon and organic nitrogen in the upper water column of the Arctic Ocean: implications for the sources of dissolved organic carbon. Deep-Sea Res. 44, 1571-1592. 